\title{
A Study of e-Learning, Blended learning, and Traditional Teaching Methods to Motivate Autonomous Learning in English Reading Comprehension of Thais Learners
}

\author{
Pornpimon Saeheng \\ Burapha University, Thailand \\ E-mail address:fai_pimol@hotmail.com
}

\begin{abstract}
:
The purposes of this study were to examine the differences in learners' satisfaction of using e-Learning, blended learning, and traditional teaching methods for TR and HI students and to study learners' autonomy after receiving three different kinds of teaching methods. The informants were 90, second year students majoring in Tourism and Hospitality Industry which were divided by purposive sampling method into three groups of 30 learners, Group A received e-Learning method, Group B received Blended Learning method, and Group $C$ received Traditional teaching style. The research instruments used for data collection were lesson plans, $e$ Learning program, learners' perception questionnaires, interview questions, and English Reading Comprehension test (Pretest and Posttest). Quantitative data were collected and analyzed by mean, standard deviation. The interview data was read, reread, and then coded. Coding organized the raw data into meaningful categories. The results of this study indicated that the overall of students' satisfaction and autonomous learning rate after receiving their teaching delivery methods were at "good." Additionally, the interview results showed that the students were positively satisfied with e-Learning and blended learning. The students have become autonomous learning. Recommendations were made and presented in two categories: benefits of future practice and further research.
\end{abstract}

Keywords: e-Learning, blended learning, traditional teaching, autonomous learning 


\section{Introduction}

As global communication expands throughout the world, studying English is important for all learners. English is probably one of the most important languages in the world today in terms of international communication. Thailand, as a part of the modern world, has an authentic need to assimilate English into the daily lives of ordinary Thai people, through both the spoken and written word. Because of this, English in all its forms has a profound impact on the Thai educational system, economics, and many other aspects of life (Genc \& Bada, 2005). With regard to this, the Ministry of Education of Thailand is attempting to raise the priority of English studies among public and private institutions in order to emphasize the significance and value of English in education.

Many educational institutions offer a variety of program for learners to study English and teach by both Thai teachers and teachers who are native Englishspeaking instructors (Baker, 2008; Kilickaya, 2009; Dueraman, 2013). In Thai educational system, English is one of the dominant languages and it has become almost a necessity for learners to study because all over the world use English as a common language and can bind the region together (Nagi, 2012). It is very clear that English language is playing a major role in the process of globalization. Therefore, teachers should provide an effective method to teach English language for the students in Thailand. However, one of the important changes in the area of learning during the past decade is the paradigm from teacher - centered to learner centered learning by using digital and electronic tools (Tsai, 2009). The appearance of using e-learning has gone beyond support learner - centered and the learners are become more autonomous learning (Lee, Cheung \& Chen, 2005).

At the present, the innovations producing Thailand education 4.0, the new age technology for education learning with virtual reality technology. The challenge is a new concept for online teaching with individual and team driven methods. Simulating the learning environments lead to realization of everything looking almost like the students actually participated in the laboratory experiments as a real experience. The development concept is to close the gap between traditional teaching and online learning. In English as a second language (ESL) and English as foreign language (EFL) students, it is necessary that teachers have access to a variety of methods which give opportunities for learners to practice and develop their English skills. However, the English as a second language (ESL) and English as a foreign language (EFL) students have problems in reading English texts. For instance, word difficulty, limited knowledge of lexical, complex sentence structure, topic, and complex noun groups are also the main causes of the problem in reading comprehension (Egbert and Ernst-Slavit, 2010). It is shown that word difficulty, topic, and complex structures of the language create reading problems for ESL/EFL students. In addition, the students lack of ability to guess meaning from the context are exhibited as problems in skimming for main ideas, scanning for details, making inferences, and finding the topics. Topic and content are also the problems for the students to inspire them to practice reading because of their needs. Another factor in 
reading comprehension is learner autonomy. Autonomy is generally as the capacity to take charge of, or responsibility for one's own learning (Shakeri, 2012).

The trends in language teaching has recently moved toward making learners more autonomous and shifting the responsibility toward the students. At the present, technology and learning have become important roles in professional lives. They have also been playing powerful roles in the classroom teaching and learning. Blended Learning is a combination of different learning methods, techniques and resources and applying them in an interactively meaningful learning environment (Sharma \& Barrett, 2007). The blended application is a learning application that integrates technology and traditional classroom teaching. It is constructed for classroom teaching and learning to enhance traditional teaching methodologies that include face-to-face activities in the regular classroom. The key to a successful blended course is planning and good design. The significance of element in blended learning is a suitable balance of traditional teaching methods and technology usage. The technology applications are supplements to teacher-developed teaching plans, but technologies are able to provide numerous benefits, including the development of independent learners, a source of instant feedback, and students' motivation (Macdonald, 2008).

In this study, the researcher tries to help the students who enroll English Specific Purpose course majoring in Tourism (TR) and Hospitality Industry (HI) pay attention and motivate in their learning especially in English reading by providing the different teaching delivery methods including e-Learning, blended as well as traditional teaching method. The students who study in the field of tourism in education are now quite important to promote tourism country and economy of the country.

\subsection{Research Questions}

The central research questions for this study were:

1. What are the effects of e-Learning, blended learning, and traditional teaching method on students' satisfaction?

2. How do the three different teaching methods promote autonomous learning?

\section{Literature Review}

\section{1 e-Learning Strategies Instruction and English Language Learning Motivation}

e-Learning has become a widely accepted method of learning and teaching in educational institutions and organizations all over the world. The e-Learning as a strategy to teach English model is developed to assist Thai students in addressing the many obstacles that challenge them. The e-Learning, as a strategy to teach English model additionally is proven to be effective, because it is perceived as being useful and addressed the authentic needs of learners, student-centered, and allows students to read their own interested materials (Quigley, 2011). Moreover, e-Learning is playing its effective role in learning a language by providing activities in each language skill in an innovative and motivating manner. Motivation and learning attitude are important predictors of achievement (Nunan, 2003). In relation with that 
statement, Slavin (2009) says that students who are highly motivated to learn something are more likely than others to consciously plan their learning, to carry out a learning plan, and to retain the information they obtain.

Motivation contributes to reading comprehension. It is evident that the acquisition of reading strategies and reading comprehension skills demands an enormous amount of effort and motivation and that outstanding teacher invest substantial time and energy in supporting students' motivation and in their reading. Hence, the process information which they read frequently with these cognitive purposes, motivated students gain in reading comprehension proficiency (Guthrie \& Hunmenick, 2004). It can be seen that motivation and reading comprehension skills go together and force the students to practice and support in their learning. If the students have a motivation in their mind, they are able to study themselves both inside and outside the classroom without teachers' directions and then they will become autonomous learners.

It has been observed that language acquisition through e-Learning is better than traditional classroom in the era of technology (Farooq, Umar, Javid, and Zahid, 2012). Recent advances in Internet and Web-based technologies have redefined the boundaries and pedagogies of distance learning by stretching its scope and deepening its interconnectedness. New learning interactions that are not perceived possible before can now be facilitated, such as the coupling of experts from around the world with novices, the instantaneous access to global resources (Dabbagh \& Bannan-Ritland, 2005). e-Learning, like all instructional technology delivery environments must be rooted in frameworks to be effective for teaching and learning. e-Learning offers many advantages compared to conventional learning. One of its advantages is the learning method which can be more adaptive than conventional learning (Budi Santoso, 2007). In the digital world, e-Learning is becoming increasingly popular among students. The issue of learning in e-Learning environments must be given a thorough attention.

In addition, e-Learning is also an innovative approach for delivering electronically mediated, well-designed, leaner-centered and interactive learning environment to anyone, anytime and anyplace by utilizing the internet and digital technologies in concern with instructional design principles (Hedge \& Haward, 2004; Gabarre,et al., 2014; Thang, et al., 2016). Similar to above, Nwokike (2010) mentions that eLearning as the use of computer as a key component of the education environment. According to Ngwoke and Numonde (2011) e-Learning have the following worth:

1. It enables you to learn when and where you want at your own pace

2. If you have commitments which make it harder for you to attend a regular course: e-Learning provides learning opportunities;

3. When you live a long way from a training area, and work irregular hours or shift, e-Learning provides learning opportunities.

Therefore, e-Learning offers a great valuable in learning process. Electronic learning is both convenient to the teacher and the learner. Learning can take place anywhere and anytime. e-Learning is a learning tool to motivate the students to study by 
themselves. Learners also enjoy having the opportunity to learn at their own pace and their own time. Moreover, it helps students to develop knowledge of internet. All these show that e-Learning has advantages for corporation, education, teachers and learners.

\subsection{Motivation and Autonomy in Language Learning Development}

Both motivation and autonomy are the factor to assist the students' success in the learning process. Firstly, motivation refers to behavior that is characterized by willingness and volition. Intrinsic motivation is animated by personal enjoyment, interest, or pleasure, whereas extrinsic motivation is governed by reinforcement contingencies. Motivation closely related beliefs, perceptions, values, interests, and actions (Emily R. Lai, 2011). Motivation plays an important role in the process of learning a language, also. Language teachers cannot effectively teach a language if they do not understand the relationship between motivation and its effect on language acquisition. Moreover, motivation also influences how high the level of the learners' language will be. The importance of motivation in increasing second/foreign language learning is incontrovertible. Lifrieri (2005) supports that "when asked about the factors which influence individual levels of success in any activity such as language learning". Most people would certainly mention motivation.

Secondly, autonomy is closely related to motivation which is the biggest concern for teachers. Motivation now seems to be a key if the class or the teacher is to be successful. Therefore, autonomy is worth investigating as a great tool to motivate learners. One of the main goals for a teacher is to assist learners become autonomous so that they will be able to deal with their own learning. Dörnyei (2005) refers that learners who can work and learn independently are able to become more successful and proficient. Küçükler (2016) argues that the autonomy based learning techniques show the importance of the teacher towards the learners' understanding of language. Similarly, $\mathrm{Wu}$ (2003) also claims that perceived autonomy in second language learning is dependent on whether the learners are provided with adequate control in their learning in terms of their objectives, processes and outcomes. A higher level of motivation was an indicator of greater engagement in outside activities which proves that motivation leads to autonomy.

Pedagogical autonomy has become a crucial concept of language teaching in today's curricula for modern language education. Learner autonomy classifies as an educational philosophy helping students with the development of lifelong learning strategies. Autonomy is of great value in language learning, cultivating autonomy in learners will be something that every teacher would like to do. Autonomy in this study helps to enhance learner motivation, because choices provide for proactive commitment and encourages students to implement self-reflection strategies. Consequently, both autonomy and motivation link together in the second language learning process. The learners are motivated to learn. They can find and study by themselves outside the classroom, frequently practice on their study, and then they become autonomous learners. Autonomous learners also draw their intrinsic 
motivation when they accept responsibility for their own learning and commit themselves to develop or practice their skills both inside and outside the classroom.

Autonomy-supportive contexts also enhance autonomous motivation and produce positive outcomes such as extensive efforts and high performance, while controlling contexts forestall autonomous motivation and develop poorly integrated forms of motivation (Boich, Sarrazin, Grouzet, Pelletier, \& Chanal, 2008; Vansteenkiste, Simons, Lens, Sheldon, \& Deci, 2004). Therefore, language learning is immediately more effective and children are more likely to remember what they have learned (Mohanty, 2010). Learners' active participation and responsibility for their own learning process are important in the field of foreign language learning. Learners become autonomous by being involved in all aspects of the learning process and the learners must have some choices and control their own learning environment. Both autonomy and motivation link together in the second language learning process. The learners are motivated to learn. They can find and study by themselves outside the classroom, frequently practice on their study, and then they become autonomous learners. Autonomous learners also draw their intrinsic motivation when they accept responsibility for their own learning and commit themselves to develop or practice their skills both inside and outside the classroom.

\subsection{Motivation for Reading Comprehension}

Motivation and learning attitude are important predictors of achievement (Nunan, 2003). In relation with that statement, Slavin (2009) says that students who are highly motivated to learn something are more likely than others to consciously plan their learning, to carry out a learning plan, and to retain the information they obtain. Motivation contributes to reading comprehension. It is evident that the acquisition of reading strategies and reading comprehension skills demands an enormous amount of effort and motivation and that outstanding teacher invest substantial time and energy in supporting students' motivation and in their reading. Moreover, motivation may influence the development of reading comprehension is that motivated students usually want to understand text content fully. Hence, the process information which they read frequently with these cognitive purposes, motivated students gain in reading comprehension proficiency (Guthrie \& Humenick, 2004).

To help the students improve their reading comprehension skill, Pardo (2004) accepts that the student should make choices in their reading selections and educators in turn should select themes and texts based on interests of the students. In addition, a selection of material encourages the use of authentic literacy. In the same way, Ivey and Broaddus (2001) support the same study results as Pardo (2004) in term of conducting a student survey regarding the interest of the process of personal reading for a student body from a school group. They would like to know what the students' needs and interests. They focus on how to select material suitably for the students. According to many researchers, increasing reading skill is related to increasing motivation to read. Students with high motivation to learn English will better prepare themselves to engage the process of teaching and learning in the classroom. They will prefer to read more books, ask many questions to teachers, do the exercises, expose themselves to English language using, trying to use their 
English skill to communicate with others, or happily engage in the process of teaching and learning English.

\subsection{Learner Autonomy and Reading Comprehension}

Learner autonomy has become a key concern in the foreign language or second language instruction context in recent decades due to the change from traditional classroom settings which students are passive learner learner-centered approaches. Autonomous learners are more active and efficient in the process of language learning and autonomous learners are more motivated to take part in various activities for learners (Zarei, A. A. \& Gahremani, K, 2010). The relationship between learner autonomy and the development of language proficiency has gone together. Dafei (2007) pointed out that effective learning is strongly affected by autonomous learning. The success of an autonomous learner depends on his activation and use of metacognitive knowledge (Little (2007). In addition, Dafei (2007) agreed that in order to promote autonomy in language skills, the learners should extend their strategies of learning beyond teacher-guided to self-guided and autonomous learning. For reading comprehension, this issue meant that students need to visible self-confidence in their ability to deal with texts and monitor their comprehension.

To become an effective teaching and learning in EFL context, teachers should play a leading role in promoting students' active participation in reading and motivate them to move away from being passive learners. In order to facilitate, this appropriate support should be available for them when necessary. The teacher should understand how to teach in ways that best correspond with students' various needs and educational backgrounds to assist students recognize the significant role. Learner autonomy can play in achieving improved student's reading comprehension ability and they feel independence to study.

\subsection{Teaching and Learning in the Blended Context}

Blended learning provides an integrated platform for online and traditional learning and the crucial factor in blended learning is the electronic support coming from eLearning. Teachers should prepare their students for the blended learning style and discuss the new roles and responsibilities. Teeley (2007) as well as (Brunner, 2007) agree that blended learning provides flexibility for institutions to engage in traditional teaching classroom and online learning by providing students with relevant meaningful content while maintaining student-teacher relationships. The concentration of a blended learning is to improve student performance and retention, giving them more time flexibility, the availability of multiple modes of learning, deeper sense of community and greater interaction. In addition, Senior (2010) emphasizes that teachers should focus on more general pedagogical outcomes and use technology as a means of virtually extending the classroom and concentrating on the learners' interests, requirements, experiences, and goals.

As EFL or ESL teachers have used the technological tools to help students expand their dedication to the lessons and explore different resources to learn a foreign language. Nevertheless, it is important to highlight how the traditional teaching 
classes and the virtual environment interact. In the studies presented, EFL or ESL teachers emphasize that why blended learning is able to use as a pedagogical model in the EFL or ESL classroom context because it can also be implemented through several perspectives and with different learning goal. Consequently, blended learning can be models from teachers that can make a difference and assist students during their learning process by promoting autonomous learning and independent work. In this study, the researcher use e-Learning as a blended learning combined with traditional teaching method to teach the students in classroom. One of the most highlighted aspects is the fact that students can develop their autonomous learning and enhance towards the English reading learning process.

\subsection{Traditional Teaching Method}

Traditional teaching is concerned with the teacher being the controller of the learning environment. The instructor dictates the structure of the lesson and the division of time. The components of traditional learning include blackboard, books, instructor and students in a classroom. Traditional learning also as a single path helps learners identify a clear direction and goal, thus a learner has a lower chance of getting lost or having trouble (Martin, 2008). In addition, traditional approach is mostly teacher centered, occurs frequently with the whole class, teacher talk exceeds student talk, and use of class time is largely determined by the teacher.

\section{Research Methodology}

This study is taught and conducted by the researcher for 15 weeks with a total of 15 sessions. The participants in this study are the sophomore students majoring in Tourism and Hospitality Industry and they are divided by purposive sampling method into three groups of 30 learners, the experimental group A received eLearning, group B received Blended Learning, and group $\mathrm{C}$ received Traditional Teaching Method.

The first session, the students of each group (A, B, C) produce the pre-test. Next, each group of students studied with their teaching delivery methods which they received. After that the students of each group (A, B, C) produce the post-test. When the students in each group finished their test, they were asked to answer the perception questionnaire. The statistics used for interpretation of the questionnaire and the questionnaires were analyzed by mean $(\bar{X})$, and standard deviation (S.D.).

Finally, student in each group were interviewed with ten questions. The finding of interview supports the findings of perception questionnaires. The data were read, reread, and then coded. Coding organized the raw data into meaningful categories.

\subsection{Data Collection}

In the $1^{\text {st }}$ session, the students of each group $(\mathrm{A}, \mathrm{B}, \mathrm{C})$ produced the pre-test. The scores were recorded. The pretest was reading comprehension test which came from reading section of the TOEFL test. Next, in the $2^{\text {nd }}$ session, the students of experimental group A started to learn the lesson on reading comprehension strategies and reading passages with e-Learning instructional design program, the students of experimental group $\mathrm{B}$ started to learn the lesson on reading 
comprehension strategies and produce reading passages with teacher for five weeks after that studied with e-Learning program for five weeks, and the students of the control group started the lesson on worksheet. Then the $3^{\text {rd }}-12^{\text {th }}$ session, the students of experimental group A started to learn the reading passage e-Learning program with exercises (1 exercise for 1 session). The students of experimental group B started to learn reading comprehension and produce reading passages with teacher for six weeks after that they studied with e-Learning program for five weeks. At the same time, the students of the control group started the reading passages with exercises on worksheet. The participants produced the exercises by themselves with the teacher as a facilitator. In the $13^{\text {th }}$ session, students in each group produced the post-test. (the same tests as the pre-test). For the $14^{\text {th }}$ session, students in each group were asked to answer the perception questionnaire. The data were analyzed with the mean $(\bar{X})$, and standard deviation $(S D)$. Finally, student in each group were interviewed with ten questions. The finding of interview supported the findings of perception questionnaires. Then, the data were coded.

\subsection{Data Analysis}

The data obtained from different methods were analyzed and interpreted in two main ways, quantitative and qualitative data analysis. Both of the data were analyzed as follows:

\subsubsection{Quantitative Data Analysis}

The following statistical analysis would be used in this study. The statistics used for interpretation of the questionnaire and the questionnaires were analyzed by mean ( $\bar{X}$ ) and standard deviation (S.D.).

\subsubsection{Qualitative data Analysis}

Interview questions, the data are read, reread, and then coded. Coding organized the raw data into meaningful categories. As coding proceeded, the researcher reorganizes the data into more precise categories. The final list of codes was used to code all the data.

Trustworthiness referred criteria for judging the quality of qualitative research. The criteria used the judge of the trustworthiness. Two dimensions of rigor or trustworthiness was applied in this study as follows:

Triangulation of data sources was applied in this research. The technique of comparing the consistency of information derived at different times and by different means within this research was applied.

Authenticity checks conducted in this study were included obtaining informed consent from all participants, and additional interview with certain participants. Consent from all participants was obtained during the interview process.

Ethical considerations were involved in this study plans. Consent forms were also developed prior to data collection and used upon request. Participants were told the purpose of the study during the first request for participation. The researcher's responsibility to the participants included obtaining consent, ensuring 
confidentiality, and avoidance of harm. Participant's confidentiality was maintained by using a number to represent each participant, rather than their names. All research-related documents were kept in a locked filing cabinet to make sure that they remained confidential and secure. The researcher had ensured that ethical issues were the first priority and had discussed the issue with each participant before the interview.

\section{Findings}

In this study, the results would be presented into two sections. The first section would be presented as quantitative data report and the final section would be presented as qualitative data report.

\subsection{The quantitative data report would be presented as the following section}

The student satisfaction toward e-Learning, blended learning, and traditional teaching method, the results were from an analysis of perception questionnaires for each group (A, B, C). The overall of learners' satisfaction after they have received their teaching method were at a "good" satisfaction level. The mean scores of students' satisfaction in group A (e-Learning) were at 4.31 and the standard deviation was at 0.538 . Then, the mean scores of students' satisfaction in group B (Blended Learning) were at 4.00 and the standard deviation was at 0.602 whereas the mean scores of students' satisfaction in group C (Traditional Teaching) were at 2.99 , and the standard deviation was at 0.584 respectively.

The student autonomous learning after receiving three different kinds of teaching methods, the results were from an analysis of perception questionnaires for each group (A, B, C). The students' autonomous learning of three groups toward the three teaching delivery methods was at "good" level. The mean scores of students' autonomous learning in Group A (e-Learning) was at 4.51, Group B (Blended Learning) was at 4.02, Group C (Traditional Teaching) was at 2.76 respectively.

\subsection{The qualitative data report would be presented as the following section.}

The qualitative data was divided into two sections. The first section would be the students' satisfaction including the category of learning experience, the category of satisfaction, and the category of suggestion and the second section would be the students' autonomous learning including the category of learning experience and the category of satisfaction. In the first section, for the category of Learning Experience, participants in group A and B expressed positive opinions toward their teaching delivery method that they received. The students gained more knowledge and could learn at their ability. Moreover, their reading skills were improved. For the category of learning experience of group $\mathrm{C}$, they stated negatively because their English reading was improved not too much, they gained less knowledge after finishing the course, and they mentioned that this teaching delivery method did not provide learning experience and focused on teacher center.

Next, the category of satisfaction of group A and B were quite similar. The participants satisfied with their teaching delivery method in terms of the appropriate program for learning and relaxed learning atmosphere. In addition the participants of 
group A satisfied with e-Learning program because the program was useful. At the same time, the participants of group B satisfied with blended learning because it provided more benefits. However, the participants of group $\mathrm{C}$ did not satisfy with their own teaching delivery method. They stated that they had dissatisfaction with traditional teaching, it was not appropriate for learning. They would like to study with technology and teacher should design the course with online course or eLearning.

Finally, the category of suggestion of each student groups (A, B, C) was different because the participants in each group expressed their different opinions. The participants from group $\mathrm{A}, \mathrm{B}$, and $\mathrm{C}$ suggested the similar point that in e-Learning program, teacher should add more detail, content, and exercises and design for another subjects, and provide e-Learning or online course for them to study whereas the participants from group B suggested that teacher should apply technology in educational instruction and separate teaching method between e-Learning and traditional teaching method. Some participants in blended learning group did not familiar to study with combining teaching style, so this made them get confuse. However, the participants from group $\mathrm{C}$ stated that one point that different from other. They suggested that teacher should change teaching delivery method instead of traditional one.

For the students' autonomous learning, there were two categories including the category of learning experience and the category of satisfaction. First, the category of learning experience, the students from group A and B expressed positively toward their teaching delivery method that they received. They mentioned that studying with e-Learning and blended learning supported their student-centered learning and they were able to practice their responsibility, punctuality, and motivation. Moreover, the participants of both group (A and B) practiced their study by themselves and this point allowed them to become autonomous learners. They felt independence during their learning with relaxing learning atmosphere. However, the students of group $\mathrm{C}$ expressed negatively with their teaching delivery method. They stated that traditional teaching method did not provide learning experience and focused on teacher center. They might not be interested in learning with it because they did not create their own learning. Everything came from teacher's framework. Autonomous learning could not be effective for them.

Second, the category of satisfaction, the students from group A and B mentioned positively. They claimed that learning environment or learning atmosphere of an eLearning program was funny and relax. They satisfied with their teaching delivery method that they received in terms of relaxed learning atmosphere. Whereas, the students from group $\mathrm{C}$ expressed negatively toward their teaching delivery method, they dissatisfied it. The students in group $\mathrm{C}$ pointed out that studying with traditional teaching method was very difficult to create learning atmosphere due to the teacher's direction and they lack of independence to study, motivation, and autonomous learning. 


\section{Discussion}

According to the research question one and two, there were two findings including findings from the questionnaires and the interview. The finding of learners' satisfactions and autonomous learning using the questionnaire after the participants have received their teaching delivery methods revealed that they were at "good" satisfaction level and autonomous learning which meant that learners were satisfied with their teaching delivery methods that they received and they have become autonomous learners. According to the results of the study, the students preferred to study with e-Learning more that blended learning and traditional teaching method.

e-Learning offered the student to study and practice their responsibility. At the beginning, this teaching method motivated them to improve their reading comprehension skill, also. Many studies have been done on motivation and have revealed correlations between level of motivation and achievement. Researchers all agreed on the effect of motivation on language learning (Dornyei, 2001a, 2005; Ehrman, Leaver \& Oxford, 2003; Graham, 2004; Semmar, 2006; Masgoret \& Gardner, 2003; Yang, 2016; Khaloufi \& Laabidi, 2017). Next, this teaching delivery method allowed students to meet their learning objectives and they have the freedom to study. They also studied by themselves without any teachers' directions. This teaching method allowed them to become learner autonomy and promoted studentcentered. This was in congruence with the studied of Hedge \& Haward (2004) and Nwokike (2010). e-Learning was an important factor to consider when teachers design the course. In addition, the students emphasized to create online learning environment, an instructor's interaction becomes far more important than in traditional classrooms because the instructor's presence is invisible. The study of Zhong (2008) and the study of Tsai (2008) also coincided that learners get autonomous by using internet or online learning that some favorable factors affect this process and they preferred online learning environments that adopt more constructivist pedagogy. Finally, the students would like all courses apply technology in education such as online course or e-Learning. This was congruence with Alu (2011) that e-Learning was the use of Information and Communication Technology (ICT) which included computer networks, communication and mobile technologies to enhance and extend learning. These technologies helped to deliver and make education and information accessible to whoever needed it.

Blended learning sounded like a nice idea-mixing a traditional class room environment with online LMS components but it might be actually effective. In this study, the results also supported those findings on students' satisfaction since either blended learning and traditional instruction holds some weaknesses and strengths. The results showed the similar points of e-Learning and blended learning in terms of learning experience including improving English reading skill, offering studentcentered learning and autonomous learning, practicing their responsibility, punctuality, and motivation and applying technology in educational instruction. It was better way to mix the strengths of both learning environments. Blended learning course provided a comprehensive and comparable learning environment to the traditional program. The students expressed the positive response to blended 
learning in terms of overall satisfaction, enjoyment of the lessons, creation of learning atmosphere, motivation to learn, support in student centered, and convenience and independence to study. This result was congruent with the study of Kongpet Dennis (2011) that a blended online learning approach model was effective for English language teaching and learning. Whereas Miyazoe's (2008) agreed that of blended learning would provide a grate motivation for students to learn when they used more technology their online participation increases. Consequently, blended learning could be used as an effective way to deliver good quality instruction as it offered educationalists and students a technology based on scaffold to student achievement and more rewarding learning experiences.

Traditional teaching approach mostly focused on teacher centered in this study. In traditional teaching approach, instruction happened frequently with the whole class. The students' satisfaction toward this teaching delivery method was at the lowest level. Most of students rarely satisfied with their teaching that they received. There were some reasons why they did not satisfy with this teaching delivery method such as focused on teacher centered, study with time limitation, had restriction for learning, lacked of motivation and learning atmosphere, and gain less learning experience. The result was congruent with the study of Selinger (2008) which pointed out that traditional learning is often limited by frameworks of a teacher's professional design and lack of motivation students to interact, ask questions or make them understand the lesson thoroughly.

The findings from interview of each group (A, B, C) were discussed in each category as follows:

1. Category of Learning Experience when asking the participants about their teaching delivery method that they received they expressed that they benefited from their learning experience and the main thing that they were able to improve their reading ability. Firstly, the participants from Group A (e-Learning) expressed positive attitude toward their teaching delivery method. They stated that their English reading skill was improved and they realized with reading strategies In addition, learning with e-Learning was very convenient and easy to access. They mentioned that they were able to access the program at any time and any place according to their needs. Furthermore, some participants ensured that this teaching delivery method promoted students centered and autonomous learning. They could interact with the program, study the lessons by themselves without teacher's direction, and organize the schedule as they needed. Quigley (2011) insisted that the e-Learning, as a strategy to teach English model was proven to be effective, because it was perceived the authentic needs of learners, student-centered, and allowed students to study their own interest.

Secondly, the participants from Group B (Blended Learning) also expressed positive attitude toward their teaching delivery method. However, a few participants mentioned negatively with blended learning. Most of participants from Group B expressed that blended learning approach assisted them to improve their English reading skill. They were able to study with traditional teaching style and e-Learning program. They gained more knowledge and learning experience. Then the 
participants expressed their opinion that blended learning promoted student-centered learning and autonomous learning and it was convenient to access. The study of Akhras (2012) insisted that blended learning supports and promotes studentcentered-learning and encourages increased student interaction, also.

Finally, the participants from Group C (Traditional Teaching) expressed negatively that they dissatisfied with traditional teaching because this teaching delivery method was not appropriate for learning. Selinger (2008) confirmed that traditional learning was limited by frameworks of a teacher's professional design and lack of motivation students to interact, ask questions or make them understand the lesson thoroughly. The main problem was that the lecture method tended to foster passiveness and dependence on the instructor, not student. Consequently, this teaching method did not promote student centered and autonomous learning.

2. Category of Satisfaction, when the participants responded the interview questions, they stated different attitude toward their teaching delivery methods that they received. The participants from Group A (e-Learning) felt satisfied with their teaching delivery method. They stated that e-Learning was useful learning media to learn and it was suitable for them to learn. Neilsen (2012) claimed that the students got benefits from using e-Learning tool. The participants from Group B (Blended Learning) felt that this teaching delivery method provided more benefits and it was appropriate for them to learn. The study of Al-Saai, A., Al-Kaabi, A., and AlMuftah, S. (2011) indicated the same result that the students had positive attitude and gain scores in favor of blended e-Learning approach. Whereas the participants from Group C (Traditional Teaching) felt negatively toward their teaching delivery method, it was not suitable for them to study for undergraduate level. Moreover, learning atmosphere was difficult to create. The participants lacked of independence, motivation, students centered, and autonomous learning. These were kinds of some restriction for this teaching delivery method as the study of Wong (2006) mentioned.

3. Category of Suggestion, the participations from Group A (e-Learning) also provided their constructive suggestions based on the development of this course. Firstly, they would like teacher to add more contents and reading with exercises in the program so that they were able to study and practice more. They would like to practice with a variety of texts at different levels of difficulty. They expressed the same opinion that this program was good. It would be more interesting if there were varieties of texts to read. There should be more reading passages, pictures, and contents. Moreover, this program should be adjusted to other educational level. The teacher should design the lesson using e-Learning or online course. The participants from Group B (Blended Learning), they also provided the constructive suggestions based on the development of the course as the participants in Group A. They mentioned that technology in education was very important now, so teacher should apply it in educational system. The participants from Group C (Traditional Teaching) provided some suggestions that related to develop the course. They suggested and emphasize on technology. The study of Alu (2011) pointed out that using Information and Communication Technology (ICT) included computer networks, communication and mobile technologies to enhance and extend learning. 
These technologies helped to deliver and made education and information accessible to whoever needed it. They also requested that teacher should apply technology in classroom, and change the teaching style from traditional teaching to online course or e-Learning. In addition, designing for another subjects using technology and providing e-Learning were considered before preparing the course.

\section{Conclusions}

Education is becoming more accessible and more learner-driven through technology. Information technology has also made a dramatic change in education in terms of creating a new method for teaching/learning and reaching out to students by using new methodology. This study aimed to isolate methods to promote autonomous learning and improve learners' reading comprehension skills. The results from this study showed that the e-Learning and blended learning would be effective teaching delivery method to motivate them to practice their English reading comprehension skill and their autonomous learning. They also expressed positive attitude toward these two teaching delivery methods.

\section{Recommendation}

On the basis of the research results, recommendations on teaching and learning and further research recommendations were made. The researcher provided these practical recommendations to inform instructors how to better adjust the teaching delivery methods in order to address the needs of the students. The following practical recommendations were provided for instructors who were designing or who were planning to teach with an interactive learning program:

Identify learners' background; e-Learning program was very useful and helpful for students to improve their reading ability. Therefore, this program could be used or modified by the instructors who would like to improve students' reading ability. Instructors should provide and design the appropriate program for students in each educational level in order to get more effectiveness.

Provide course orientation as early as possible; instructors should give students their user manual before the class begins. After that, the instructors should demonstrate how to use a task-based interactive learning program and show students the step-bystep procedures on how to use it.

Provide variety of contents and exercises; instructors should design the various lesson activities in the program in order to motivate and support students' understanding while they were reading. In addition, instructors provide more resources for students to search more deeply information. These would help students reduce their stress and promote their autonomous learning.

The instructors should be more organized and conscientious than for conventional classroom teaching; to design the program the instructors should add more learning exercises and activities like games to reduce stress while the students studied. 
Provide assistance, and require students to participate as much as possible; the instructor should provide assistance, give consistent and timely feedback, and allow time for students to study.

In addition, this study also could recommend for further research as follow:

1. The study should be carried out in other English skills such as writing, speaking, and listening skills.

2. A similar research should conducted involving students for another education level and field such as students in third year majoring in English because they will need more new teaching delivery teaching method.

3. A comparative study should be conducted to compare teaching delivery method with e-Learning with other teaching delivery method or approaches such as web-based learning or online collaborative learning.

4. According to the student suggestions from the interview, they satisfied with e-Learning teaching delivery method. The study should be carried out in other subjects such as English for Tour Guide, Mathematics, and subjects in general education areas because the program would allow them to practice the lessons, motivate them to study by themselves, increase their learning experience and atmosphere, and encourage their autonomous learning and students centered.

\section{References}

Akhras, C. (2012).Virtual classrooms and the discussion forum: A Net Benefit for Business Students. International Journal of Business and Social Science, 3(11), 1-7.

Al-Saai, A., Al-Kaabi, A., and Al-Muftah, S. (2011). Effect of a blended e-learning environment on students' achievement and attitudes toward using e-learning in teaching and learning at the university level. International Journal for Research in Education (IJRE), 29, 34-55.

Albalawi, B. R. (2015). The effect of different teaching delivery methods (Face-toface, Virtual and Blended) on intermediate students' academic achievement. West East Journal of Social Sciences, 4(1/2), 29-45.

Alu, N. C. (2011). Utilizing e-learning in science and technology education problems and prospects. In Onyegegbu, O. and Eze, U. (Eds). Optimizing elearning opportunities for effective education service delivery. A Publication of the Institute of Education, University of Nigeria Nsukka.

Baker, W. (2008). Should culture be an overt component of EFL instruction outside of English speaking countries? The Thai context. Asian EFL Journal. Retrieved October, 21, 2010, from http://www.asian-efljournal.com/dec_03_sub. wb.php.

Boiche, J. C. S., Sarrazin, P. G., Grouzet, F. M., Pelletier, L. G., \& Chanal, J. P. (2008). Students' motivational profiles and achievement outcomes in physical 
education: A self-determination perspective. Journal of Educational Psychology, 100(3), 688-701.

Brunner, D., L. (2007). Using "Hybrid" effectively on Christian higher education. Christian Scholar's Review, 36(2), 115.

Budi Santoso, H. (2007). Pemodelan personalisasi Pembelajaran berdasarkan Aspek Gaya Belajar pada student centered e-learning environment, Faculty of Computer Science, University of Indonesia, Master Thesis.

Dabbagh, N., \& Bannan-Ritland, B. (2005). Online learning: Concepts, strategies, and application. Upper Saddle River, NJ: Prentice Hall.

Dafei, D. (2007). An Exploration of the Relationship between Learner Autonomy \& English Proficiency. Asian ELT Journal, 24, 1-24.

Dornyei, Z.. (2005). The Psychology of the language learner. London: Lawrence Erlbaum Associates.

Dueraman, B., (2013). Focus on Thai learners of English: Their self-reports about foreign language learning. International Research Journal of Arts and Social Sciences, 2(7).

Egbert, J. L., \& Ernst-Slavit, G. (2010). Access to academics: Planning instruction for $k$ - 12 classrooms with ELs. Boston, MA: Pearson Education.

Ehrman, M. E., Leaver, B. L., and Oxford, R. L. (2003). A brief overview of individual differences in second language learning. System, 31, 313-330.

Emily R. Lai (2011). Motivation: A Literature Review, Research Report. Retrieve August 26, 2017 from http://images.pearsonassessments.com/images/tmrs/Motivation_Review_final. pdf

Farooq, Umar, M., Javid, and Zahid, C. (2012). Attitude of students towards elearning: A study of english language learners at Taif university english language centre. NUML Journal of Critical Inquiry; Retrieve April 25, 2017 from http://connection.ebscohost.com.

Gabarre,et al. (2014). iPads in the foreign language classroom: A learner's perspective, 3L: Language, Linguistics, Literature ${ }^{\circledR}, 20$ (1), 2014

Genc, B., \& Bada, E. (2005). Culture in language learning and teaching. The Reading Matrix, 5(1), 73-84.

Graham, S. J. (2004). Giving up on modern foreign languages? Students' perceptions of learning French. The Modern Language Journal, (88)2, 171191. New York.

Guthrie, J. T., \& Humenick, N. M. (2004). Motivating students to read: Evidence for classroom practices that increase reading motivation and achievement. In. $\mathrm{P}$. McCardle \& V. Chhabra (Eds.), The voice of evidence in reading research (pp. 329-354).

Hedge, N., and Hayward, L. (2004). Reading roles: University e-Learning contributing to life-long learning in networked world.www.nationamaster.com.

Ivey, G. \& Broaddus, K. (2001). Just plain reading: A survey of what makes students want to read in middle school classrooms. International Reading Association, 36 (9), 350. 
Khaloufi, Az-eddine \& Laabidi, Hicham. (2017). An Examination of the Impact of Computer Skills on the Effective Use of ICT in the Classroom. Indonesian Journal of EFL and Linguistics, 2(1), 2017

Kilickaya, F. (2009). World englishes, english as an international language and applied linguistics. English language teaching, Ccsenet Journal, 2(3), 35-39.

Kongpet Dennis, N. (2011). Development of a blended online learning approach model for English for careers in Technology at Ubon Ratchathani Rajabhat University. A Thesis Submitted in Partial Fulfillment of the Requirements for the Degree of Doctor of Philosophy in English Language Studies

Suranaree University of Technology.

Küçükler, Halil. (2016). Autonomous Learning for Proficiency Level in Foreign Language Development of Graduate Students. Indonesian Journal of EFL and Linguistics, 1(2), 2016

Lee, M. K. O., Cheung, C. M. K. \& Chen, Z. (2005). Acceptance of internet-based learning medium: The role of extrinsic and intrinsic motivation. Information \& Management, vol. 42, 1095-1104.

Lifrieri, V. (2005). A sociological perspective on motivation to learn EFL: The case of escuelas plurilingües in Argentina. M.A thesis, University of Pittsburgh.

Little, D. (2007). Language Learner Autonomy: Some Fundamental Considerations Revisited. ELT Journal, 1, 14-29.

MacDonald, J. (2008). Blended Learning and Online Tutoring: Planning Learner Support and Activity Design (Second Edition). Burlington, VT: Gower.

Martin, F. (2008). Blackboard as the learning management system of a computer literacy course. MERLOT J. online Learning and Teaching, 4(2), 138-145.

Masgoret, A. M. and Gardner, R. C. (2003). Attitudes, motivation, and second language learning: A Meta-Analysis of Studies Conducted By Gardner and Associates. Language Learning, 53(1), 123-163.

Miyazoe, T. (2008). LMS-based EFL blended learning: Blackboard vs. Moodle. Retrieved from http://es.scribd.com/doc/62898287/LMS-Based-EFLBlending-Learning-Blackboard-vs- Moodle

Mohanty, D. (2010). Implementing learner autonomy in Indian language classroom. MJAL, 2(5), 334-345.

Nagi, K.(2012). Learning english language in Thailand: Hype or Necessity?: The Nation. retrieved on January 21, 2016 from http://www.nationmultimedia.com/opinion/Learning-English-language-inThailand-Hype-or-Nece-30179150.html.

Ngwoke, D. U. and Numonde, D. (2011).Optimizing e-learning opportunities for effective education service delivery: A case for use of E-textbook in Schools.inOnyegegbu, N. and Eze, U. (eds) Optimizing E-learning Opportunities for Effective Education Service Delivery. Publication of Institute of Education: University of Nigeria, Nsukka.

Nwokike, F.O. (2010). Accounting education for sustainable entrepreneurship. International Technology Education Journal, 1(1), 57-63.

Nunan, D. (2003). Collaborative language learning and teaching. Cambridge: Cambridge University Press. 
Pardo, L. (2004). What every teacher needs to know about comprehension. International Reading Association, 58 (3). 272-280.

Quigley, D. (2011). e-Learning as a Strategy to Teach English in Thailand: A Professional Development Model to Support Teacher Growth. US-China Education Review A 5 (2011) 624-631.

Selinger, M. (2008). "Communication technology in schools" Retrieved December 21, 2016, from http://www.imfundo.org/papers/cit-in-s.doc.

Senior, R. (2010). Connectivity: A framework for understanding effective language teaching in face-to-face and online learning communities. RELC Journal, 41(2), 137-147. http://dx.doi.org/10.1177/0033688210375775.

Semmar, Y. (2006). An exploratory study of motivational variables in a foreign language learning context. Journal of Language and Learning, 5(1), 118-132.

Shakeri, H. (2012). The relationship among EFL learners' autonomy, tolerance of ambiguity, reading strategies, and reading comprehension. A Thesis Submitted in Partial Fulfillment of The Requirements for The Degree of Master of Arts In Teaching English As A Foreign Language (TEFL). Islamic Azad University Central-Tehran Branch Faculty of Foreign Languages English Department.

Sharma, P., \& Barrett, B. (2007). Blended Learning: Using technology in and beyond the language classroom. Macmillan Publishers.

Slavin, Robert E. (2009). Educational psychology: Theory and Practice. NewJersey: pearson Education, Inc.

Thang, et al. (2016). ICT Tools Patterns of Use among Malaysian ESL Undergraduates, . GEMA Online, 16(1), 2016

Teeley, K. H. (2007). Designing hybrid web-based courses for accelerated nursing students. Educational Innovations, 46( 9).

Tsai, C. (2008). The preferences toward constructivist internet-based learning environments among university students in Taiwan. Computers in Human Behavior, 24(2), 16-31.

Tsai, M.-J. (2009). The Model of Strategic e-Learning: Understanding and Evaluating Student e-Learning from Metacognitive Perspectives. Educational Technology \& Society, 12 (1), 34-48.

Vansteenkiste, M., Simons, J., Lens, W., Sheldon, K. M., \& Deci, E. L. (2004). Motivating learning, performance, and persistence: The synergistic effects of intrinsic goal.

Wong, J. (2006). Traditional versus hybrid courses. International Journal of Learning, 13 (8), 163-170.

$\mathrm{Wu}, \mathrm{X}$. (2003). Intrinsic motivation and young learners: The impact of the classroom environment. System, 31, 502-517.

Yang, Pei-Ling. (2016). In-Class Online Discussion Activities to Enhance EFL Learners' English Self-Efficacy and Language Learning Strategies. ASIAN TEFL, 1(2), 2016

Zarei, A. A. \& Gahremani, K. (2010). On the relationship between learner autonomy and reading comprehension. TELL 3(10), 81-99. Retrieved on August 26, 2017 from http://www.ikiu.ac.ir/public-files/profiles/items/090ad_1424769045.pdf. 
Zhong, Y. (2008). A Study of Autonomy English Learning on the Internet. Foreign Language Department of Qinzhou University Qinzhou 535000,China.

\section{Author:}

Pornpimon Saeheng

Degree of Doctorate of Education Teaching English as a Global Language International Graduate Studies Human Resource Development Center

Faculty of Education, Burapha University, Thailand

E-mail address:fai_pimol@hotmail.com

Mobile Phone: 089-771-0468. 